\title{
Dyslipidemia: Genetics, lipoprotein lipase and HindIII
}

\section{polymorphism [version 1; peer review: 1 approved, 1 approved}

\section{with reservations]}

\author{
Marcos Palacio Rojas (iD) 1,2, Carem Prieto2, Valmore Bermúdez (iD)2,3, \\ Carlos Garicano3 ${ }^{3}$ Trina Núñez Nava1, María Sofía Martínez², Juan Salazar (iD2, \\ Edward Rojas , Arturo Pérez4, Paulo Marca Vicuña1, Natalia González Martínez" \\ Santiago Maldonado Parra1', Kyle Hoedebecke (1D)5,6, Rosanna D'Addosio (D)7, \\ Clímaco Cano², Joselyn Rojas ${ }^{8}$
}

\footnotetext{
${ }^{1}$ Hospital Básico de Paute, Public Health Ministry, Paute, Ecuador

2Endocrine and Metabolic Diseases Research Center, School of Medicine, University of Zulia, Maracaibo, Venezuela

${ }^{3}$ Grupo de Investigación Altos Estudios de Frontera (ALEF), Universidad Simón Bolívar, Cúcuta, Colombia

${ }^{4}$ Department of Medicine, Rutgers University, Newark, NJ, 07103, USA

5 Yongsan Health Clinic, Seoul, 96205, South Korea

6WONCA Polaris - USA, Bangkok, 10500, Thailand

${ }^{7}$ Department of Public Health, School of Medicine, University of Zulia, Maracaibo, Venezuela

${ }^{8}$ Division of Pulmonary and Critical Care Medicine, Brigham and Women's Hospital, Harvard Medical School, Boston, MA, 02115, USA
}

V1 First published: 30 Nov 2017, 6:2073

https://doi.org/10.12688/f1000research.12938.1

Latest published: 01 Oct 2018, 6:2073

https://doi.org/10.12688/f1000research.12938.2

\section{Abstract}

The direct link between lipid metabolism alterations and the increase of cardiovascular risk are well documented. Dyslipidemias, including isolated high LDL-c or mixed dyslipidemia, such as those seen in diabetes (hypertriglyceridemia, high LDL-c or low HDL-c), correlate with a significant risk of cardiovascular and cerebrovascular disease worldwide. This review analyzes the current knowledge concerning the genetic basis of lipid metabolism alterations, emphasizing lipoprotein lipase gene mutations and the HindIII polymorphism, which are associated with decreased levels of triglycerides and LDL-C, as well as higher levels of HDL-c. These patterns would be associated with decreased global morbidity and mortality, providing protection against cardiovascular and cerebrovascular diseases.

\section{Keywords}

Dyslipidemia, Polymorphisms, HindIII, Lipoprotein Lipase, coronary artery disease

\section{Open Peer Review \\ Approval Status \\ 1 \\ 2 \\ version 2 \\ (revision) \\ 01 Oct 2018 \\ version 1 \\ 30 Nov 2017

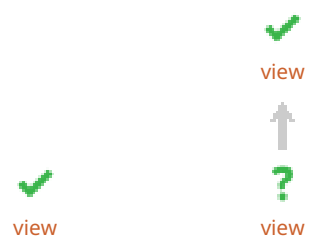 \\ 1. David J. Galton, The Royal London and St. Bartholomew's Hospitals, London, UK \\ 2. Carlos Aguilar-Salinas (DD, Unidad de Investigación de Enfermedades Metabólicas, México City, Mexico}

Any reports and responses or comments on the article can be found at the end of the article. 
Corresponding author: Marcos Palacio Rojas (marcos.palacio@gmail.com)

Author roles: Palacio Rojas M: Conceptualization, Data Curation, Investigation, Methodology, Project Administration, Supervision, Validation, Writing - Original Draft Preparation; Prieto C: Conceptualization, Data Curation, Formal Analysis, Writing - Original Draft Preparation; Bermúdez V: Conceptualization, Data Curation, Formal Analysis, Investigation, Methodology, Project Administration, Resources, Supervision, Validation, Visualization, Writing - Original Draft Preparation; Garicano C: Conceptualization, Data Curation, Project Administration, Validation, Visualization; Núñez Nava T: Conceptualization, Data Curation, Investigation, Validation; Martínez MS: Conceptualization, Data Curation, Investigation; Salazar J: Conceptualization, Data Curation, Investigation; Rojas E:

Conceptualization, Data Curation, Resources; Pérez A: Data Curation, Formal Analysis, Writing - Original Draft Preparation; Marca Vicuña P: Data Curation, Formal Analysis, Investigation, Methodology; González Martínez N: Data Curation, Resources, Software; Maldonado Parra S: Conceptualization, Validation, Visualization; Hoedebecke K: Methodology, Project Administration, Writing Original Draft Preparation, Writing - Review \& Editing; D’Addosio R: Conceptualization, Data Curation, Writing - Original Draft Preparation, Writing - Review \& Editing; Cano C: Data Curation, Writing - Original Draft Preparation; Rojas J: Conceptualization, Supervision, Writing - Original Draft Preparation

Competing interests: No competing interests were disclosed.

Grant information: This work was supported by the Technological, Humanistic, and Scientific Development Council (Consejo de Desarrollo Científico, Humanístico y Tecnológico; CONDES), University of Zulia (grant n CC-0437-10-21-09-10).

The funders had no role in study design, data collection and analysis, decision to publish, or preparation of the manuscript.

Copyright: ( 2017 Palacio Rojas M et al. This is an open access article distributed under the terms of the Creative Commons Attribution License, which permits unrestricted use, distribution, and reproduction in any medium, provided the original work is properly cited.

How to cite this article: Palacio Rojas M, Prieto C, Bermúdez V et al. Dyslipidemia: Genetics, lipoprotein lipase and HindIII polymorphism [version 1; peer review: 1 approved, 1 approved with reservations] F1000Research 2017, 6:2073

https://doi.org/10.12688/f1000research.12938.1

First published: 30 Nov 2017, 6:2073 https://doi.org/10.12688/f1000research.12938.1 


\section{Dyslipidemia: The current status}

The relationship between dyslipidemia and atherosclerosis continues to be an area of active research, since the prevalence of atherosclerosis and associated cardiovascular complications continue to increase in the industrialized world ${ }^{1}$. Cardiovascular disease (CVD) constitutes the greatest cause of morbidity and mortality globally with a high incidence in countries of all economic categories ${ }^{2}$. Evidence supporting a causal relationship between lipid profile abnormalities and the risk of coronary artery disease (CAD) is overwhelming, confirming that hypercholesterolemia is an independent risk factor for $\mathrm{CVD}^{3-5}$. In addition, hypertriglyceridemia and mixed dyslipidemias have been associated with the aggregation of metabolic risk factors, like hypertension $(\mathrm{HTN})^{6}$ and obesity ${ }^{7}$.

Dyslipidemias are a group of metabolic derangements characterized by any or a combination of the following: elevated low density lipoprotein (LDL-c) $(>130 \mathrm{md} / \mathrm{dL})$, elevated total cholesterol ( $>200 \mathrm{mg} / \mathrm{dL})$, elevated TG $(>150 \mathrm{mg} / \mathrm{dL})$, or low high density lipoprotein (HDL-c) $(<40 \mathrm{mg} / \mathrm{dL}$ in men and $<50 \mathrm{mg} / \mathrm{dL}$ in women $)^{8}$.

The worldwide prevalence of dyslipidemia varies between different individuals, depending on race, age, socio-economic and cultural factors, lifestyle and genetics. This prevalence has increased significantly in growing cities with economic growth ${ }^{9}$. According to the National Health and Nutrition Examination Survey (NHANES) 2003-2006, 53.0\% of the adult population in United States has some form dyslipidemia ${ }^{10}$; however, a lower prevalence have been reported for other countries, for example Canada and South Korea, with $45 \%$ and $44.1 \%$, respectively ${ }^{8,11}$. De Souza et al. studied a sample of 1,039 patients and reported that the most common dyslipidemias in Brazil were isolated low HDL-c (18.3\%), hypertriglyceridemia (17.1\%), and isolated hypercholesterolemia $(4.2 \%)^{12}$. These results are similar to those reported by Aguilar-Salinas et al., in which the incidence of dyslipidemia in a group of 4,040 Mexican patients was $60.3 \%$, from which low HDL-c represented 60.3\%, hypercholesterolemia $43.6 \%$ and hypertriglyceridemia $31.5 \%{ }^{13}$. Another crosssectional and descriptive study carried out in 318 patients from Cuenca, Ecuador, found that $82.4 \%$ of individuals $(86.8 \%$ in females and $76.5 \%$ in males) had some type of dyslipidemia. Isolated low HDL-c was the most prevalent abnormality and it was significantly associated with obesity (OR: 3.99. CI: $95 \%$. $1.65-9.36 ; \mathrm{p}<0.01)^{14}$.

In Venezuela, the CARMELA study evaluated the prevalence of lipid metabolism disorders in the city of Barquisimeto of Lara state, reporting one of the highest percentages in the country, with a $50.4 \%$ prevalence of dyslipidemia in this population ${ }^{15}$. Nevertheless, a study by Linares et al. ${ }^{16}$ with a sample of 2,230 individuals from Maracaibo City, Venezuela, identified the overall dyslipidemia prevalence was even higher at $84.8 \%$ $(n=1892)$, where $88 \%$ of females and $81.4 \%$ of males were found to have dyslipidemia. High LDL-c was the most frequent abnormality found in this population (20\%), followed by the combination of low HDL-c with high LDL-c (19\%) and hypertriglyceridemia with high LDL-c and low HDL (16.2\%). Bermúdez et al. ${ }^{17}$ found that low HDL-c was statistically associated with obesity, ethnic group, alcohol consumption, and elevated TG.

\section{Dyslipidemia genetics}

The association between family history of dyslipidemia and the risk of CVD is supported by a large body of evidence ${ }^{18-22}$. Additionally, the great advancement in DNA analysis techniques has aided research surrounding CVD and related genetics and epigenetics. Understanding gene mutations or polymorphisms involved in the synthesis, transport, and metabolism of lipoproteins allows recognition of potential therapeutic targets and alternative treatments through identification of new molecules ${ }^{1,3,20}$.

Dyslipidemia is one of the most well characterized cardiovascular risk factors ${ }^{19,20}$. This not only depends on diet, but also on the synthesis and metabolism of lipoproteins conditioned by gene expression. Given the importance and the great diversity of proteins that participate in lipid metabolism, one might expect that a single defect in any step of gene expression would affect the quantity or quality of the product and potentially predispose to dyslipidemias and $\mathrm{CVD}^{19}$.

One genetic abnormalities associated with low HDL-c and increased CVD risk is the Taq IB polymorphism located in chromosome 16q21. This gene alters cholesteryl ester protein transferase (CEPT), which decreases HDL-c concentration ${ }^{23}$. Some deletions, inversions, and substitutions of the APO AI-IV, CII, and $C I I I$ genes are also associated with both premature CVD and low HDL-c ${ }^{24,25}$. Total deficiency of lecithin cholesterol acyl transferase (LCAT) can be seen after transition of $\mathrm{C} \rightarrow \mathrm{T}$ in codon 147 of exon 4 (W147R), G $\rightarrow$ A in codon 293 of exon 6 (M293I), as well as partial deficiencies of LCAT due to transition of $\mathrm{C} \rightarrow \mathrm{T}$. Additionally, the substitution of threonine for isoleucine in codon 123 (T123I) causes decreased HDL-c and higher cholesterol in the intima of arterial vessels ${ }^{26,27}$.

Below, some of the genetic alterations associated with low levels of HDL-c and a higher risk of CVD are highlighted:

1. CETP. The transcript of this gene mediates the exchange of lipids between lipoproteins, resulting in a net transference of cholesteryl esters from HDL to other lipoproteins and the capture of cholesterol in the liver. High levels of CETP lead to HDLs rich in TG, making a substrate for hepatic lipases, so that TG are hydrolyzed and ApoA-I is degraded in renal tubule cells. The subsequent decrease in HDL-c concentration creates a pro-atherogenic environment ${ }^{28}$. This occurs when CETP reaches a high level of expression in some individuals with polymorphisms in the codifying CETP gene (16q21). Being the most frequently occurring and best characterized polymorphism on intron 1, TaqIB is associated with the development of early atherosclerosis ${ }^{23}$.

2. Familial hypoalphalipoproteinemia and HDL-C deficiency. Approximately 50\% of HDL-c alterations are explained by polygenic defects in various chromosomal loci that control apolipoprotein expression (A-I, A-II, C-II, C-III and Apo $A-I V)$ and LCAT. Multiple genetic defects have been 
reported, such as deletions, inversions and substitutions on codifying genes of apolipoproteins, which are all associated with premature arterial disease $\mathrm{e}^{24,25}$.

3. LCAT. This liver-synthesized enzyme circulates in plasma forming complexes with HDL and participating in the inverse transport of cholesterol. An LCAT deficiency results in the accumulation of free cholesterol on tissues. Insertions and substitutions in the LCAT gene may cause inactivation of the protein. Some of the reported mutations are $\mathrm{C} \rightarrow \mathrm{T}$ transitions on codon 147 of exon 4 (W147R), $\mathrm{G} \rightarrow \mathrm{A}$ on codon 293 of exon 6 (M293I), and the insertion of 3 pair of bases on exon 4 , introducing a glycine on a helicoidally region of the protein and a substitution $\mathrm{N} 228 \mathrm{~K}^{24,25}$. The best characterized mutation is a $\mathrm{C} \rightarrow \mathrm{T}$ transition that results in a substitution of threonine for isoleucine in codon 123 (T123I) of the protein, resulting in a partial deficiency of $\operatorname{LCAT}^{29,30}$.

The following are some genetic alterations associated with hypercholesterolemia and hypertriglyceridemia, including their relationship with increased cardiovascular risk:

1. LDLR gene - LDL-c receptor and familial hypercholesterolemia. LDL-c is a macromolecular complex that transports cholesterol and cholesteryl esters from the liver to other peripheral tissues, where cholesterol is introduced to the cells through LDL receptors (LDLR). LDL binds to its receptors before internalization by endocytosis ${ }^{31}$. This transport represents the principal mechanism that regulates cholesterol concentration in plasma. Any defect in this transport results in hypercholesterolemia. Mutations in the LDLR gene that codifies the LDL-c receptor is one the best characterized genetic defects causing dyslipidemia. This autosomal dominant condition is called familial hypercholesterolemia ${ }^{32,33}$. Familial hypercholesterolemia is characterized by elevated levels of cholesterol and LDL-c as a consequence of defects in cholesterol transportation, receptor deficits, or a functional alteration of cellular receptors.

2. APO B-100 gene - ligand of LDL-c receptor and Familial Apolipoprotein $B$ dysfunction (hypercholesterolemia type $B$ ). An inadequate cholesterol transport also caused by genetic defects in the ligand of LDLR, the $A P O$ B-100. This autosomal dominant defect, also known as familial $A P O B-100$ dysfunction, comes from mutations in $A P O B-100$ gene, in the short arm of chromosome $2^{34}$. The first mutation described is a $\mathrm{G} \rightarrow \mathrm{A}$ transition that results in a substitution of $\operatorname{Arg} 3500 \rightarrow$ Gln on the $A P O B-100$ receptor of LDL-c ${ }^{33,35}$. Similarly, there are mutations associated with hypercholesterolemia and elevated TG that correlate with elevated CVD risk. Mutations of the LDL-r gene is the cause of familial hypercholesterolemia, which causes elevation of both total and LDL-c cholesterol ${ }^{27,28}$, and APO B-100 mutations located in $\mathrm{p} 2$ (transition $\mathrm{G} \rightarrow \mathrm{A}$ is the best known), resulting in a substitution of $\mathrm{Arg} 3500 \rightarrow \mathrm{G} 1 \mathrm{n}$ in the region of APO B-100 that binds to LDL-c ${ }^{29}$, leading to type B hypercholesterolemia ${ }^{35}$.
3. APO E gene-Apolipoprotein E and hyperlipoproteinemia or hyperlipidemia type III. Apolipoprotein E (ApoE) is a principal component of chylomicrons $(\mathrm{CMs})$, very low density lipoprotein (VLDL) and some HDL-c. Its main function is the hepatic clearance of CMs and VLDL, as well as lipolysis by the same lipoprotein lipase (LPL) ${ }^{36}$. In hyperlipoproteinemia or hyperlipidemia type III, plasma levels of cholesterol and TG increases as a consequence of defective transport of CMs and VLDL, due to a defect in the ApoE gene located on the short arm of chromosome 19 $(19 q 13.2)^{37,38}$. Polymorphisms in the codifying gene of ApoE (alleles $\varepsilon 2,3$ y 4) ) $^{39,40}$ are associated with variations in plasma levels of cholesterol, where the individuals with $\varepsilon 2$ allele have $10 \%$ lower cholesterol levels compared to those who express the $\varepsilon 4$ allele, leading to cholesterol values $10 \%$ above the mean of homozygous individuals for $\varepsilon 3$., leads to hyperlipoproteinemia or type III hyperlipidemia with elevated total cholesterol and elevated $\mathrm{TG}^{41,42}$.

4. Lp(a) gene - lipoprotein $(a)-L p(a)$. Lipoprotein(a) is composed by a common low density lipoprotein (LDL-col) nuclei linked to an apolipoprotein (a) [Apo(a)] by disulfide bonds between a cysteine in the Kringle-IV type 9 (Cys 67) and the cysteine 3734 in Apo B-100 ${ }^{43}$. Structurally, Apo(a) is composed of heavily glycosylated tridimensional structures called "Kringle" because of their similarity with a looped Danish pastry. Each Kringle contains a mean of 80 amino acids stabilized by 3 internal disulfide bonds, which finally surround the LDL molecules ${ }^{43}$. Apo(a) has high structural similarity with plasminogen, a key proenzyme of the fibrinolytic pathway ${ }^{44}$. Kringle IV domains are classified into 10 distinct subclasses, which compose most of the Apo(a) molecule, plus a linked Kringle V domain that resembles the catalytic region of plasminogen. The Kringle IV type 2 domain gene can be expressed a different number of times, resulting in a variable copy number of this structure (3-40 copies) within the $\mathrm{Lp}(\mathrm{a})$ molecule ${ }^{44}$. This determines the basis for the isoform size heterogeneity of Apo(a), whereas, the remaining 9 subtypes of Kringle IV are expressed just in a single copy into the Apo(a) molecule. Lp(a) is one of the most important cardiovascular risk markers ${ }^{45,46}$ and to date, some polymorphisms in the Apo(a) gene, located on chromosome 6 (6q26-q27) have been identified. For example, KIV-2 CNV consists of variable numbers of repeated units of module 4 and the number of repetitions inversely correlates with plasma levels of $\mathrm{Lp}(\mathrm{a})^{47}$.

5. HL gene - hepatic lipase and phenotype of combined familial hyperlipidemia. Combined familial hyperlipidemia is a genetic lipid disorder that accounts for 10-20\% of premature CAD worldwide. Affected individuals' exhibit hypercholesterolemia and/or hypertriglyceridemia and elevated concentrations of $A P O B$, with low values of HDL-c. These are collectively called iatrogenic lipoproteinemia phenotype. There have been demonstrations of alterations in common genetic loci between families of both combined familial hyperlipidemia phenotype and iatrogenic lipoproteinemia phenotype. Such loci include genes of superoxide manganese dismutase, transport 
proteins of cholesteryl esters/lecithin, cholesterol acyl transferase and $A I-C I I I-A I V$, as well as a great variety of studies relating polymorphisms in the promoter region of the $L H$ gene (C-480T and C-514T polymorphisms) with lowering on plasma levels of HDL-c $\mathrm{c}^{48,49}$.

6. LPL gene - lipoprotein lipase, Apo CII and familial dyslipidemia type $O$ or familial chylomicronemia. Any mutations on the LPL gene, which results in a partial deficiency of the enzyme, will cause an increase in TG concentration. This is the basis of familial chylomicronemia, familial dyslipidemia type I or familial hypertriglyceridemia ${ }^{50}$. These are monogenic diseases with autosomal recessive inheritance, consisting with pure hypertriglyceridemia, TG values of 300 to $800 \mathrm{mg} / \mathrm{dl}$, cholesterol $<240 \mathrm{mg} / \mathrm{dl}$, increases in VLDL and CMs, and lowering of LDL-c and HDL-c. To date, some LPL variants have been characterized because of amino acids substitutions in different positions (D9N, N291S, substitutions of glycine for glutamine on codon 188 and serine for a termination signal on codon $447)^{51}$. The enzymatic activity of LPL is also lowerd by mutations on the ApoC2 gene, located on chromosome $19 q$ and codifies an essential activator of $\mathrm{LPL}^{52}$.

This information justifies the use of genetic markers for early diagnosis and cardiovascular risk assessment, especially in children and adolescents, in order to adopt early nutritional or pharmacologic interventions with the aim to mitigate atherosclerotic artery disease.

\section{Lipoprotein lipase}

The $L P L$ gene is located on the short arm of chromosome 8, on the region 21.3 (8p21.3). It is formed of 10 exons and 9 introns (Figure 1), and the gene codifies a protein of 475 amino $\operatorname{acids}^{53,54}$.

$L P L$ is a multifunctional glycoprotein enzyme that plays an important role on lipid metabolism. After being secreted, it adheres to the luminal surface of endothelial cells where it hydrolyzes TG in circulating lipoproteins. This constitutes the limiting step on lipoprotein elimination, such as CMs from exogenous sources, and those endogenous sources, like VLDL, in circulation $^{55,56}$.

In this way, $L P L$ affects serum levels of TG, generating lipoprotein remnants that are processed by hepatic lipase. Recently, it has been demonstrated that $L P L$ serves as a ligand for the protein related to the LDLR and influences hepatic secretion and VLDL and LDL-c capture ${ }^{57}$. Additionally, $L P L$ has been linked to the retention of LDL-c by the sub-endothelial matrix and arterial wall, increasing LDL and VLDL conversion into more atherogenic forms ${ }^{58}$. Genetic modifications can affect $L P L$ activity, which results in changes in lipid metabolism. Examples are slow hydrolysis of CMs and VLDL-c, longer LDL-c half-life, and decreased production of $\mathrm{HDL}^{59,60}$.

Around 100 mutations have been described on the $L P L$ gene. The most frequent are Asp9sn, Gly188Glu and Asn291Ser. The mutations in the homozygous form are associated with hyperlipoproteinemia type I (familial chylomicronemia). Heterozygous mutations have a significant incidence in the general population $(3-7 \%)$ and leads to up to a $50 \%$ decreased activity of $L P L$, causing an increase in TG and a decrease in HDL-c. All these lipid profile patterns increase the risk of $\mathrm{CVD}^{61}$.

\section{LPL gene polymorphisms}

Genetic studies have revealed around 100 mutations and polymorphisms in simple nucleotides on the $L P L$ gene, some are protective, which others are deleterious:

1. Ser447x (rs328) polymorphism is located in exon 9, where cytosine is substituted by guanine on position 1959. This polymorphism leads to the suppression of both final amino acids, serine and glycine on position 447 of the protein that codifies a $L P L$ protein prematurely truncated, which has increased lipolytic activity and increased levels of post-heparin LPL activity in X447 carriers. This is associated with the variant Ser447X, with low levels of TG, small increases of HLD-c levels, and a moderate CVD risk reduction ${ }^{62}$.

2. Pvull (rs285) polymorphism, located on intron 6, is located $1.57 \mathrm{~kb}$ from the Splicing Acceptor (SA) site. This polymorphism is the product of a change of cytosine for thymine. The region that contains the Pvull site is similar to the site of splicing, which interferes with the correct splicing of mRNA. However, the physiological role of this polymorphism is not completely clear yet, since it does not alter the serum concentration of lipids, nor the amino acid sequence, and a previous meta-analysis suggests that cardiovascular risk is not influenced by this polymorphism $^{63}$.

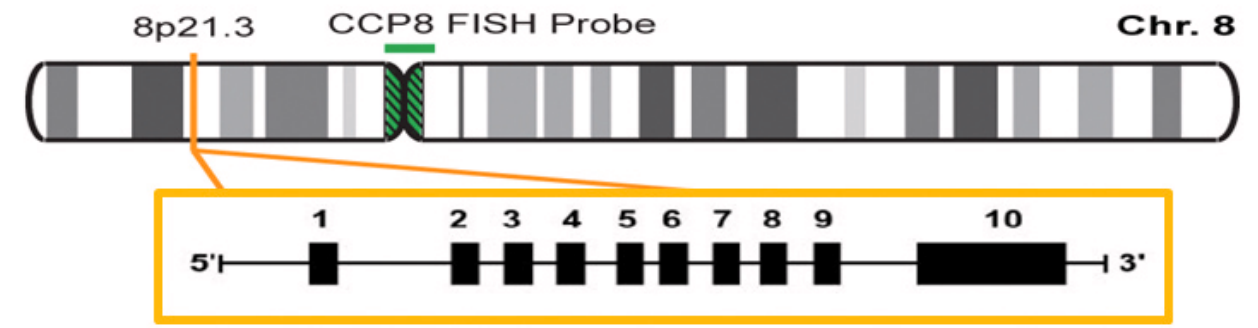

Figure 1. Chromosomal origin of the LPL gene. The authors confirm that this is an original image and has not been re-used or adapted from another source. 
3. HindIII (rs320) polymorphism is one of the most common polymorphisms of $L P L$ gene (see below).

\section{HindIII (rs320) polymorphism}

HindIII is a transition of intronic bases of thymine (T) to guanine $(\mathrm{G})$ on position 495 of intron 8 of the $L P L$ gene, which eliminates the restriction site for the HindIII enzyme (Figure 2 and Figure 3).

HindIII is one the most frequent polymorphisms found in various studies, which show that the homozygous genotype $\mathrm{T} / \mathrm{T}$

$$
\begin{aligned}
& 5^{\prime} \ldots \text { A }^{\mathbf{\top}} \text { G G C T T . . . 3 } \\
& 3^{\prime} \ldots \text { T T C G A.A ... }
\end{aligned}
$$

Figure 2. Recognition sequence of HindIII enzyme. The authors confirm that this is an original image and has not been re-used or adapted from another source.
$\left(\mathrm{H}^{+} / \mathrm{H}^{+}\right)$represents from 45.1 to $56.4 \%$ of Iranian and south Indian populations, respectively most frequent, followed by the heterozygous T/G with $35.8-36.6 \%$ and homozygous G/G $\left(\mathrm{H}^{-} / \mathrm{H}^{-}\right)$, with $6.93-19 \%{ }^{64,65}$. Similar results have been reported in Europe $^{66,67}$ and Brazil ${ }^{68}$.

The allele $\mathrm{H}+$ (presence of thymine " $\mathrm{T}$ " or restriction site of HindIII enzyme) results in a cut on the base pair sequence in two bands of $217 \mathrm{pb}$ and $139 \mathrm{pb}$. This is associated with a decrease in the activity of $L P L$ in comparison with the allele $\mathrm{H}$ - (presence of "G" or absence of the enzymatic restriction site or presence of HindIII polymorphism). With $137 \mathrm{pb}$, in which there is no cut in the $L P L$ gene intron 8 sequence, maintaining a unique sequence of $356 \mathrm{pb}$ (Figure 4$)^{69}$, leading to both alterations in lipidic metabolism and cardiovascular risk profile modifications in these populations.

Some studies have demonstrated that the common allele ( $\mathrm{T}$ or $\mathrm{H}+$ ) is associated with lower levels of HDL-c in contrast with

\begin{tabular}{|c|c|c|c|c|c|}
\hline \multirow[t]{5}{*}{ INTRON 8} & \multirow{2}{*}{$\begin{array}{l}\text { B GTATTAAAT } \\
\text { CCTGGATAAT }\end{array}$} & \multirow{2}{*}{$\begin{array}{l}\text { GTATTTTCT } \\
\text { CAAAGATTCA }\end{array}$} & \multicolumn{2}{|c|}{$\ldots--(\approx 330 \mathrm{bp}) \ldots$} & \multirow{2}{*}{$\begin{array}{l}\text { CGAGATGCTA } \\
\text { GTGAGATTCC }\end{array}$} \\
\hline & & & AACCAACCTC & TTCCAGAAGG & \\
\hline & AAGATAATCT & CAACCTGTCT & CCGCAGCCCC & CTGT & ACC CATAAAA \\
\hline & TGAATTACAC & AGAGATCGCT & ATAGGA & & ACTAAATGTG \\
\hline & CTGGGATTTT & GCAAACTATA & GTGTGCTGTT & ATTGTTAATT & TAAAAAA \\
\hline
\end{tabular}
the uncommon allele $(\mathrm{G} \text { or } \mathrm{H}-)^{70,71}$. In addition, those individuals

Figure 3. Intron 8, restriction site of HindIII (AAGCTT > AAGCGT). The authors confirm that this is an original image and has not been re-used or adapted from another source.

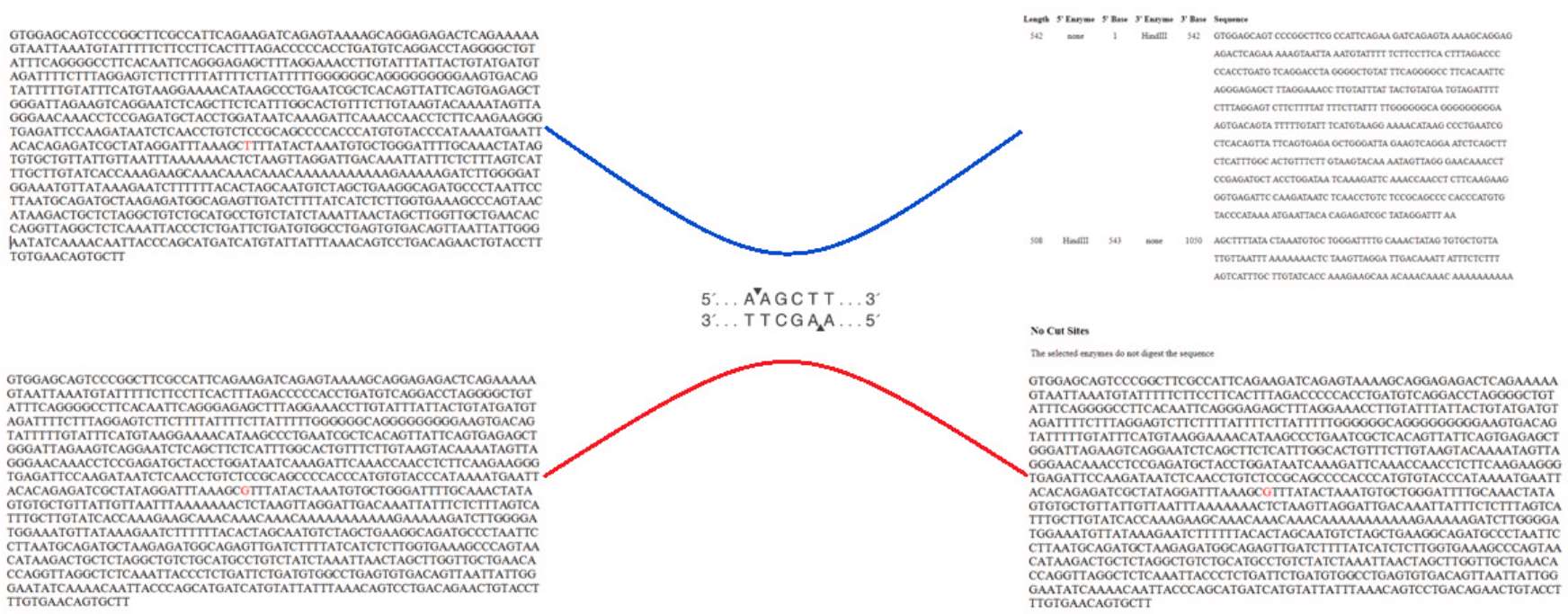

Figure 4. Enzymatic restriction sites in HindIII ${ }^{69}$. The authors confirm that this is an original image and has not been re-used or adapted from another source. 
with $\mathrm{H}+/ \mathrm{H}+$ genotype had a higher concentration of serum levels of TG when compared with homozygous genotype $\mathrm{H}_{-} / \mathrm{H}^{-66,67,70,72}$. Similarly, there have been reports of high serum levels of LDL-c ${ }^{71}$ and a higher global cardiovascular risk in patients who carry the common allele ( $\mathrm{T}$ or $\mathrm{H}+$ ), see Table 1 . Some studies had reported a significant drop in the $L P L$ activity among carriers of the uncommon $\mathrm{G}$ allele when compared with the more common allele $\mathrm{T}^{57}$.

$L P L$ expressed by macrophages and other cells contained in the vascular walls is involved in the early atherogenic process and is associated with increased atherosclerosis. Overexpression of $L P L$ is also associated with insulin resistance and HTN by increased sodium retention, inflammation, vascular remodeling, sympathetic nervous system activation, oxidative stress and vasoconstriction $^{73-75}$.

On the other hand, HTN (mostly systolic) has been shown to be associated with the polymorphism HindIII in the Mexican population in studies by Muñoz-Barrios et al. ${ }^{76}$. Similarly, the homozygous genotype for the common allele $(\mathrm{H}+)$ was associated with a higher risk of myocardial infarction in patients older than 90 years old in contrast with carriers of the uncommon allele (H-), associated with a lower prevalence of cardiovascular complications ${ }^{77}$. Clear associations were found between genotypes of LPL HindIII with HTN $(\mathrm{H}+/ \mathrm{H}+$ with an OR: 2.13; 95\% CI: $0.93-4.8)^{72}$ and smoking ${ }^{58}$. In a more recent study, it was established that the presence of homozygous genotype for the common allele $(\mathrm{H}+/ \mathrm{H}+)$ of the $L P L$ gene is a risk factor for a first episode of myocardial infarction ${ }^{65}$. Conversely, studies by Imeni et al..$^{78}$ in an Iranian population, showed no statistically significant associations between CAD and genotypic distributions of HindIII polymorphism.

Recent studies have shown increased risk of stroke among those with LPL gene variations, particularly in the HindIII gene $^{79}$. He et al. reported a lower risk of stroke among patients with HindIII polymorphisms with allele $\mathrm{G}$ ( $\mathrm{G}$ vs $\mathrm{T}$; $\mathrm{OR}=0.78$, $\mathrm{CI} 95 \%=0.70-0.87, \mathrm{p}<0.001)$. This pattern was observed in patients with ischemic stroke ( $\mathrm{G}$ vs T. OR=0.84, CI95\% $=074-0.95, \mathrm{p}=0.005$ ) and hemorrhagic stroke ( $\mathrm{G}$ vs. T; OR=0.60, CI95\% $=0.48-0.74$, $\mathrm{p}<0.001)^{80}$.

Table 1. Lipid disorders according LPL gene allele e6,67,70-72. $^{6}$.

\begin{tabular}{|l|l|l|l|}
\hline Serum lipid levels & Triglycerides & LDL & HDL \\
\hline Common allele $(\mathbf{H + )}$ & High & High & Low \\
\hline Uncommon allele (H-) & Low & Low & High \\
\hline
\end{tabular}

From a neurologic point of view, there is scant data associating homozygous common genotype $(\mathrm{H}+/ \mathrm{H}+)$ with the development of Alzheimer's disease of late appearance. This is founded on the $L P L$ function in regulation cognitive function, mediated by cholesterol and Vitamin E transport to neuronal cells on the hippocampus and other brain areas ${ }^{64}$. These investigations appear to indicate that the HindIII polymorphism might exert a positive influence in human metabolism, which translates into improved cardiac and cerebrovascular function.

\section{Conclusions}

Dyslipidemias are independent risk factors for atherosclerotic artery disease. High TC, TAG and LDL-C, as well as decreased serum HDL-C, are frequently associated with low physical activity and poor eating habits, but there is a large number of mutations and single nucleotide polymorphism related to a specific protein dysfunction within major lipoprotein metabolism pathways like CETP, ApoA, LCAT, LDL receptor, Apo B-100 and LPL.

In this regard, the $L P L$ gene HindIII polymorphism (rare allele $\mathrm{H}-)$ poses a protective function through its role in producing an improved lipid profile (low TG and LDL-c and high HDL-c). On the other hand, the presence of common allele ( $\mathrm{T}$ or $\mathrm{H}+$ ) is associated with pro-atherogenic dyslipidemias and raised cardiovascular risk. The uncommon allele ( $\mathrm{G}$ or $\mathrm{H}-)$ with an absence of restriction HindIII enzyme exhibits a lower prevalence of at least $20 \%$ according to the current available literature.

There are no studies in Venezuela that allows us to know the true prevalence of the HindIII polymorphism, nor to corroborate the association with changes in the lipid profile or an increased risk for cardiovascular diseases, so we suggest performing a national populational genetic study in search for this lipidic disorders with the aim to has a better understanding of the cardiovascular risk factors in Latin America.

\section{Competing interests}

No competing interests were disclosed.

\section{Grant information}

This work was supported by the Technological, Humanistic, and Scientific Development Council (Consejo de Desarrollo Científico, Humanístico y Tecnológico; CONDES), University of Zulia (grant $\mathrm{n}^{\circ} \mathrm{CC}-0437-10-21-09-10$ ).

The funders had no role in study design, data collection and analysis, decision to publish, or preparation of the manuscript. 
1. Helkin A, Stein JJ, Lin S, et al:: Dyslipidemia Part 1--Review of Lipid Metabolism and Vascular Cell Physiology. Vasc Endovascular Surg. 2016; 50(2): 107-18. PubMed Abstract | Publisher Full Text

2. Murray CJ, Lopez AD: Mortality by cause for eight regions of the world: Global Burden of Disease Study. Lancet. 1997; 349(9061): 1269-76. PubMed Abstract | Publisher Full Text

3. Gordon DJ, Probstfield JL, Garrison RJ, et al: High-density lipoprotein cholesterol and cardiovascular disease. Four prospective American studies. Circulation. 1989; 79(1): 8-15.

PubMed Abstract | Publisher Full Text

4. Isomaa B, Almgren $\mathrm{P}$, Tuomi $\mathrm{T}$, et al.: Cardiovascular morbidity and mortality associated with the metabolic syndrome. Diabetes Care. 2001; 24(4): 683-9. PubMed Abstract | Publisher Full Text

5. Carr MC, Brunzell JD: Abdominal obesity and dyslipidemia in the metabolic syndrome: importance of type 2 diabetes and familial combined hyperlipidemia in coronary artery disease risk. J Clin Endocrinol Metab. 2004; 89(6): 2601-7.

PubMed Abstract | Publisher Full Text

6. Onat A, Hergenç G, Sari I, et al.: Dyslipidemic hypertension: distinctive features and cardiovascular risk in a prospective population-based study. $A m \mathrm{~J}$ Hypertens. 2005; 18(3): 409-16.

PubMed Abstract | Publisher Full Text

7. Brown $\mathrm{CD}$, Higgins $\mathrm{M}$, Donato $\mathrm{KA}$, et al.: Body mass index and the prevalence of hypertension and dyslipidemia. Obes Res. 2000; 8(9): 605-19.

PubMed Abstract | Publisher Full Text

8. Joffres M, Shields M, Tremblay MS, et al:: Dyslipidemia prevalence, treatment, control, and awareness in the Canadian Health Measures Survey. Can J Public Health. 2013; 104(3): e252-257.

PubMed Abstract | Publisher Full Text

9. İlhan Ç, Beytullah Y, Şemsettin Ş, et al.: Serum lipid and lipoprotein levels, dyslipidemia prevalence, and the factors that influence these parameters in a Turkish population living in the province of Tokat. Turk J Med Sci. 2010; 40(5): 771-82

Publisher Full Text

10. Tóth PP, Potter D, Ming EE: Prevalence of lipid abnormalities in the United States: the National Health and Nutrition Examination Survey 2003-2006. J Clin Lipidol. 2012; 6(4): 325-30.

PubMed Abstract | Publisher Full Text

11. Lee MH, Kim HC, Ahn SV, et al.: Prevalence of Dyslipidemia among Korean Adults: Korea National Health and Nutrition Survey 1998-2005. Diabetes Metab J. 2012; 36(1): 43-55

PubMed Abstract | Publisher Full Text | Free Full Text

12. de Souza LJ, Souto Filho JT, de Souza TF, et al.: Prevalence of dyslipidemia and risk factors in Campos dos Goytacazes, in the Brazilian state of Rio de Janeiro. Arq Bras Cardiol. 2003; 81(3): 249-64. PubMed Abstract | Publisher Full Text

13. Aguilar-Salinas CA, Gómez-Pérez FJ, Rull J, et al.: Prevalence of dyslipidemias in the Mexican National Health and Nutrition Survey 2006. Salud Publica Mex. 2010; 52 Suppl 1: S44-53

PubMed Abstract | Publisher Full Text

14. Chiqui RA, Bermúdez V, Añez R, et al:: Prevalencia de dislipidemia y factores asociados en la ciudad de Cuenca, Ecuador. Síndrome Cardiometabólico. 2014 4(2): $31-41$

Reference Source

15. Vinueza R, Boissonnet $\mathrm{CP}$, Acevedo $\mathrm{M}$, et al.: Dyslipidemia in seven Latin American cities: CARMELA study. Prev Med. 2010; 50(3): 106-11. PubMed Abstract | Publisher Full Text

16. Linares $\mathrm{S}$, Bermúdez $\mathrm{V}$, Rojas $\mathrm{J}$, et al.: Prevalencia de dislipidemias y factores psicobiológicos asociados en individuos adultos del municipio Maracaibo, Venezuela. Síndrome Cardiometabólico. [Internet]. 2015; 3(3): 63-75.

17. Bermúdez V, Salazar J, Rojas J, et al.: Prevalence, Lipid Abnormalities Combinations and Risk Factors Associated with Low HDL-C Levels in Maracaibo City, Venezuela. J J Commun Med. 2015; 1(2): 9. Reference Source

18. Miller M: Dyslipidemia and cardiovascular risk: the importance of early prevention. QJM. 2009; 102(9): 657-667. PubMed Abstract | Publisher Full Text | Free Full Text

19. Lusis AJ, Rotter JI, Sparkes RS, et al.: Molecular Genetics of Coronary Artery Disease: Candidate Genes and Processes in Atherosclerosis. Monographs in Human Genetics. Karger, 1992; 14: I-XVII.

Publisher Full Text

20. Genest JJ Jr, Martin-Munley SS, McNamara JR, et al.: Familial lipoprotein disorders in patients with premature coronary artery disease. Circulation. 1992; 85(6): 2025-2033.

PubMed Abstract | Publisher Full Text

21. Aulchenko YS, Ripatti S, Lindqvist I, et al:: Loci influencing lipid levels and coronary heart disease risk in 16 European population cohorts. Nat Genet. 2009; 41(1): 47-55

PubMed Abstract | Publisher Full Text | Free Full Text
22. Nordestgaard BG, Chapman MJ, Humphries SE, et al.: Familial hypercholesterolaemia is underdiagnosed and undertreated in the genera population: guidance for clinicians to prevent coronary heart disease: consensus statement of the European Atherosclerosis Society. Eur Heart $J$. 2013; 34(45): 3478-90a.

PubMed Abstract | Publisher Full Text | Free Full Text

23. Boekholdt SM, Sacks FM, Jukema JW, et al.: Cholesteryl ester transfer protein TaqIB variant, high-density lipoprotein cholesterol levels, cardiovascular risk, and efficacy of pravastatin treatment: individual patient meta-analysis of 13,677 subjects. Circulation. 2005; $111(3)$ : 278-87.

PubMed Abstract | Publisher Full Text

24. Ikewaki $\mathrm{K}$, Matsunaga $\mathrm{A}, \mathrm{Han} \mathrm{H}$, et al:: A novel two nucleotide deletion in the apolipoprotein A-I gene, apoA-I Shinbashi, associated with high density lipoprotein deficiency, corneal opacities, planar xanthomas, and premature coronary artery disease. Atherosclerosis. 2004; 172(1): 39-45. PubMed Abstract | Publisher Full Text

25. Paulweber B, Friedl W, Krempler F, et al.: Genetic variation in the apolipoprotein Al-CIII-AIV gene cluster and coronary heart disease. Atherosclerosis. 1988; 73(2-3): 125-133.

PubMed Abstract | Publisher Full Text

26. Holleboom AG, Daniil G, Fu X, et al.: Lipid oxidation in carriers of lecithin: cholesterol acyltransferase gene mutations. Arterioscler Thromb Vasc Biol. 2012; 32(12): 3066-75.

PubMed Abstract | Publisher Full Text | Free Full Text

27. Funke $\mathrm{H}$, Von Eckardstein A, Pritchard $\mathrm{PH}$, et al.: Genetic and phenotypic heterogeneity in familial lecithin: cholesterol acyltransferase (LCAT) deficiency. Six newly identified defective alleles further contribute to the structural heterogeneity in this disease. J Clin Invest. 1993; 91(2): 677-83. PubMed Abstract | Publisher Full Text | Free Full Text

28. de Grooth GJ, Klerkx AH, Stroes ES, et al:: A review of CETP and its relation to atherosclerosis. J Lipid Res. 2004; 45(11): 1967-74.

PubMed Abstract | Publisher Full Text

29. Saeedi R, Li M, Frohlich J: A review on lecithin:cholesterol acyltransferase deficiency. Clin Biochem. 2015; 48(7-8): 472-5.

PubMed Abstract | Publisher Full Text

30. Levinson SS, Wagner SG: Implications of reverse cholesterol transport: recent studies. Clin Chim Acta. 2015; 439(Supplement C): 154-61.

PubMed Abstract | Publisher Full Text

31. Brown MS, Goldstein JL: A receptor-mediated pathway for cholesterol homeostasis. Science. 1986; 232(4746): 34-47.

PubMed Abstract | Publisher Full Text

32. Hobbs HH, Brown MS, Goldstein JL: Molecular genetics of the LDL receptor gene in familial hypercholesterolemia. Hum Mutat. 1992; 1(6): 445-66. PubMed Abstract | Publisher Full Text

33. Soria LF, Ludwig EH, Clarke HR, et al.: Association between a specific apolipoprotein B mutation and familial defective apolipoprotein B-100. Proc Natl Acad Sci U S A. 1989; 86(2): 587-91.

PubMed Abstract | Publisher Full Text | Free Full Text

34. Fouchier SW, Defesche JC, Kastelein JJ, et al.: Familial defective apolipoprotein B versus familial hypercholesterolemia: an assessment of risk. Semin Vasc Med. 2004; 4(3): 259-64.

PubMed Abstract | Publisher Full Text

35. Gaffney D, Reid JM, Cameron LM, et al.: Independent mutations at codon $\mathbf{3 5 0 0}$ of the apolipoprotein B gene are associated with hyperlipidemia. Arterioscle Thromb Vasc Biol. 1995; 15(8): 1025-9.

PubMed Abstract | Publisher Full Text

36. Mahley RW, Innerarity TL, Rall SC Jr, et al.: Plasma lipoproteins: apolipoprotein structure and function. $J$ Lipid Res. 1984; 25(12): 1277-1294.

PubMed Abstract

37. Mahley RW, Huang Y, Rall SC Jr: Pathogenesis of type III hyperlipoproteinemia (dysbetalipoproteinemia): questions, quandaries, and paradoxes. J Lipid Res. 1999; 40(11): 1933-1949.

PubMed Abstract

38. Kypreos KE, Li X, van Dijk KW, et al.: Molecular mechanisms of type III hyperlipoproteinemia: The contribution of the carboxy-terminal domain of ApoE can account for the dyslipidemia that is associated with the E2/E2 phenotype. Biochemistry. 2003; 42(33): 9841-9853.

PubMed Abstract | Publisher Full Text

39. Zannis VI, Breslow JL, Utermann G, et al:: Proposed nomenclature of apoE isoproteins, apoE genotypes, and phenotypes. J Lipid Res. 1982; 23(6): 911-914. PubMed Abstract

40. Hixson JE, Vernier DT: Restriction isotyping of human apolipoprotein E by gene amplification and cleavage with Hhal. J Lipid Res. 1990; 31(3): 545-548. PubMed Abstract

41. Arráiz N, Bermúdez V, Prieto C, et al:: Association between apoliprotein E gene polymorphism and hypercholesterolemic phenotype in Maracaibo, Zulia state, Venezuela. Am J Ther. 2010; 17(3): 330-336.

PubMed Abstract | Publisher Full Text

42. Eichner JE, Dunn ST, Perveen G, et al.: Apolipoprotein E polymorphism and 
cardiovascular disease: a HuGE review. Am J Epidemiol. 2002; 155(6): 487-495 PubMed Abstract | Publisher Full Text

43. Schmidt K, Noureen A, Kronenberg F, et al.: Structure, function, and genetics of lipoprotein (a). J Lipid Res. 2016; 57(8): 1339-1359.

PubMed Abstract | Publisher Full Text | Free Full Text

44. Bucci M, Tana C, Giamberardino MA, et al.: Lp (a) and cardiovascular risk: Investigating the hidden side of the moon. Nutr Metab Cardiovasc Dis. 2016; 26(11): 980-986.

PubMed Abstract | Publisher Full Text

45. Bermúdez V, Arraiz N, Cano C, et al:: Lipoprotein (a): molecular and epidemiologic basis about its role in cardiovascular diseases. Revista Latinoamericana de Hipertensión. 2008; 3(4): 113-122. Reference Source

46. Bermúdez V, Arraiz N, Rojas E, et al:: Abnormally high lipoprotein (a) levels in african-american communities from venezuela faced to other africandescending populations: are ethnic origins related? Revista Latinoamericana de Hipertensión. 2008; 3(3): 66-72.

Reference Source

47. Parson W, Kraft HG, Niederstätter $\mathrm{H}$, et al:: A common nonsense mutation in the repetitive Kringle IV-2 domain of human apolipoprotein (a) results in a truncated protein and low plasma Lp (a). Hum Mutat. 2004; 24(6): 474-480. PubMed Abstract | Publisher Full Text

48. Verma P, Verma DK, Sethi R, et al.: The rs2070895 (-250G/A) Single Nucleotide Polymorphism in Hepatic Lipase (HL) Gene and the Risk of Coronary Artery Disease in North Indian Population: A Case-Control Study. J Clin Diagn Res. 2016; 10(8): GC01-06.

PubMed Abstract | Publisher Full Text | Free Full Text

49. Eller $P$, Schgoer $W$, Mueller T, et al.: Hepatic lipase polymorphism and increased risk of peripheral arterial disease. J Intern Med. 2005; 258(4): 344-8. PubMed Abstract | Publisher Full Text

50. Stroes E, Moulin P, Parhofer KG, et al.: Diagnostic algorithm for familial chylomicronemia syndrome. Atheroscler Suppl. 2017; 23(Supplement C): 1-7. PubMed Abstract | Publisher Full Text

51. Clee SM, Loubser O, Collins J, et al:: The LPL S447X cSNP is associated with decreased blood pressure and plasma triglycerides, and reduced risk of coronary artery disease. Clin Genet. 2001; 60(4): 293-300.

PubMed Abstract | Publisher Full Text

52. Baggio G, Manzato E, Gabelli C, et al.: Apolipoprotein C-Il deficiency syndrome. Clinical features, lipoprotein characterization, lipase activity, and correction of hypertriglyceridemia after apolipoprotein C-II administration in two affected patients. J Clin Invest. 1986; 77(2): 520-527.

PubMed Abstract | Publisher Full Text | Free Full Text

53. Oka K, Tkalcevic GT, Nakano T, et al: Structure and polymorphic map of human lipoprotein lipase gene. Biochim Biophys Acta. 1990; 1049(1): 21-6. PubMed Abstract | Publisher Full Text

54. Deeb SS, Peng RL: Structure of the human lipoprotein lipase gene. Biochemistry. 1989; 28(10): 4131-5. PubMed Abstract | Publisher Full Text

55. Eckel RH: Lipoprotein lipase. A multifunctional enzyme relevant to common metabolic diseases. N Engl J Med. 1989; 320(16): 1060-8. PubMed Abstract | Publisher Full Text

56. Wang H, Eckel RH: Lipoprotein lipase: from gene to obesity. Am J Physiol Endocrinol Metab. 2009; 297(2): E271-288. PubMed Abstract | Publisher Full Text

57. Fernández-Borja M, Bellido D, Vilella E, et al:: Lipoprotein lipase-mediated uptake of lipoprotein in human fibroblasts: evidence for an LDL receptorindependent internalization pathway. J Lipid Res. 1996; 37(3): 464-81. PubMed Abstract

58. Daoud MS, Ataya FS, Fouad D, et al:: Associations of three lipoprotein lipase gene polymorphisms, lipid profiles and coronary artery disease. Biomed Rep. 2013; 1(4): 573-82.

PubMed Abstract | Publisher Full Text | Free Full Text

59. Gerdes C, Gerdes LU, Hansen PS, et al:: Polymorphisms in the lipoprotein lipase gene and their associations with plasma lipid concentrations in 40-yearold Danish men. Circulation. 1995; 92(7): 1765-9. PubMed Abstract | Publisher Full Text

60. Heizmann C, Kirchgessner T, Kwiterovich PO, et al.: DNA polymorphism haplotypes of the human lipoprotein lipase gene: possible association with high density lipoprotein levels. Hum Genet. 1991; 86(6): 578-84. PubMed Abstract | Publisher Full Text

61. Petrescu-Dănilă E, Voicu PM, lonescu CR: [Mutagenic aspects of the lipoprotein lipase gene]. Rev Med Chir Soc Med Nat lasi. 2006; 110(1): 173-7. PubMed Abstract

62. Groenemeijer BE, Hallman MD, Reymer PW, et al.: Genetic variant showing a positive interaction with beta-blocking agents with a beneficial influence on lipoprotein lipase activity, HDL cholesterol, and triglyceride levels in coronary artery disease patients. The Ser ${ }^{447}$-stop substitution in the lipoprotein lipase gene. REGRESS Study Group. Circulation. 1997; 95(12): 2628-2635. PubMed Abstract | Publisher Full Text

63. Cagatay P, Susleyici-Duman B, Ciftci C: Lipoprotein lipase gene Pvull polymorphism serum lipids and risk for coronary artery disease: metaanalysis. Dis Markers. 2007; 23(3): 161-6. PubMed Abstract | Publisher Full Text | Free Full Text

64. Sayad A, Noruzinia M, Zamani M, et al:: Lipoprotein Lipase HindIII Intronic Polymorphism in a Subset of Iranian Patients with Late-Onset Alzheimer's Disease. Cell J. 2012; 14(1): 67-72. PubMed Abstract | Free Full Text

65. Tanguturi PR, Pullareddy B, Krishna BR, et al.: Lipoprotein lipase gene HindIII polymorphism and risk of myocardial infarction in South Indian population. Indian Heart J. 2013; 65(6): 653-657.

PubMed Abstract | Publisher Full Text | Free Full Text

66. Georges JL, Régis-Bailly A, Salah D, et al.: Family study of lipoprotein lipase gene polymorphisms and plasma triglyceride levels. Genet Epidemiol. 1996 13(2): 179-92.

PubMed Abstract | Publisher Full Text

67. Mattu RK, Needham EW, Morgan R, et al:: DNA variants at the LPL gene locus associate with angiographically defined severity of atherosclerosis and serum lipoprotein levels in a Welsh population. Arterioscler Thromb. 1994; 14(7): 1090-7. PubMed Abstract | Publisher Full Text

68. Rios DL, Vargas AF, Ewald GM, et al.: Common variants in the lipoprotein lipase gene in Brazil: association with lipids and angiographically assessed coronary atherosclerosis. Clin Chem Lab Med. 2003; 41(10): 1351-6. PubMed Abstract | Publisher Full Text

69. Larson I, Hoffmann MM, Ordovas JM, et al:: The lipoprotein lipase HindIII polymorphism: association with total cholesterol and LDL-cholesterol, but not with HDL and triglycerides in 342 females. Clin Chem. 1999; 45(7): 963-8. PubMed Abstract

70. Razzaghi H, Aston CE, Hamman RF, et al:: Genetic screening of the lipoprotein lipase gene for mutations associated with high triglyceride/low HDLcholesterol levels. Hum Genet. 2000; 107(3): 257-67.

PubMed Abstract | Publisher Full Text

71. Holmer SR, Hengstenberg C, Mayer B, et al.: Lipoprotein lipase gene polymorphism, cholesterol subfractions and myocardial infarction in large samples of the general population. Cardiovasc Res. 2000; 47(4): 806-12. PubMed Abstract | Publisher Full Text

72. Hemimi N, Salam ME, Abd-Elwahab M: The Lipoprotein Lipase HindIII Polymorphism And The Susceptibility To Hypertension. Egypt J Biochem Mol Biol. 2009; 27(1). Publisher Full Text

73. Goodarzi MO, Guo X, Taylor KD, et al.: Lipoprotein lipase is a gene for insulin resistance in Mexican Americans. Diabetes. 2004; 53(1): 214-20.

PubMed Abstract | Publisher Full Text

74. Mead JR, Cryer A, Ramji DP: Lipoprotein lipase, a key role in atherosclerosis? FEBS Lett. 1999; 462(1-2): 1-6.

PubMed Abstract | Publisher Full Text

75. McFarlane SI, Banerji M, Sowers JR: Insulin resistance and cardiovascular disease. J Clin Endocrinol Metab. 2001; 86(2): 713-8. PubMed Abstract | Publisher Full Text

76. Muñoz-Barrios S, Guzmán-Guzmán IP, Muñoz-Valle JF, et al: Association of the HindIII and S447X polymorphisms in LPL gene with hypertension and type 2 diabetes in Mexican families. Dis Markers. 2012; 33(6): 313-20. PubMed Abstract | Publisher Full Text | Free Full Text

77. Malygina NA, Melent'ev AS, Kostomarova IV, et al: [Connection of HindIIIpolymorphism in the lipoprotein lipase gene with myocardial infarct and life span in elderly ischemic heart disease patients]. Mol Biol (Mosk). 2001; 35(5): 787-91.

PubMed Abstract

78. Imeni M, Hasanzad M, Naji T, et al: Analysis of the association Hind III Polymorphism of Lipoprotein Lipase gene on the risk of coronary artery disease. Res Mol Med. 2013; 1(3): 19-24. Publisher Full Text

79. Shimo-Nakanishi Y, Urabe T, Hattori N, et al.: Polymorphism of the lipoprotein lipase gene and risk of atherothrombotic cerebral infarction in the Japanese. Stroke. 2001; 32(7): 1481-6.

PubMed Abstract | Publisher Full Text

80. He T, Wang J, Deng WS, et al: Association between Lipoprotein Lipase Polymorphism and the Risk of Stroke: A Meta-analysis. J Stroke Cerebrovasc Dis. 2017; 26(11): 2570-2578.

PubMed Abstract | Publisher Full Text 


\section{Open Peer Review}

\section{Current Peer Review Status:}

\section{Version 1}

Reviewer Report 05 March 2018

https://doi.org/10.5256/f1000research.14029.r31173

(C) 2018 Aguilar-Salinas C. This is an open access peer review report distributed under the terms of the Creative Commons Attribution License, which permits unrestricted use, distribution, and reproduction in any medium, provided the original work is properly cited.

\section{Carlos Aguilar-Salinas}

Instituto Nacional de Ciencias Médicas y Nutrición, Unidad de Investigación de Enfermedades Metabólicas, México City, Mexico

Authors of the paper "Dyslipidemia: Genetics, lipoprotein lipase and HindIII polymorphism" summarizes several papers published by Latin American researchers about lipid disorders. The document highlight the need for more studies about genetics of dyslipidemia in this region.

The main limitations of the study are:

The paper covers a large number of topics. As a result, information is presented without a critical analyses. Since the HindIII polymorphism is the main issue under review, a large proportion of the review could be summarized and the HindIII polymorphism data extended. For example, the genes involved in familial hypoalphalipoproteinemia are enlisted partially (i.e. ABCA1 was not mentioned). It is not clear the reason to devote several paragrapjs for $\mathrm{FH}$ genes when they are not related with the main topic of this review.

Reasons for the large differences in the prevalence of the lipid disorders between LatinAmerican surveys could be critically discussed.

The style of the manuscript could be upgraded. The flow of the information should be improved.

It is kindly suggested to consider a redesign of the structure of the document.

Is the topic of the review discussed comprehensively in the context of the current literature?

Partly

Are all factual statements correct and adequately supported by citations? Partly 
Is the review written in accessible language?

Partly

Are the conclusions drawn appropriate in the context of the current research literature? Partly

Competing Interests: No competing interests were disclosed.

I confirm that I have read this submission and believe that I have an appropriate level of expertise to confirm that it is of an acceptable scientific standard, however I have significant reservations, as outlined above.

Reviewer Report 19 January 2018

https://doi.org/10.5256/f1000research.14029.r30011

(C) 2018 Galton D. This is an open access peer review report distributed under the terms of the Creative Commons Attribution License, which permits unrestricted use, distribution, and reproduction in any medium, provided the original work is properly cited.

\section{David J. Galton}

Wolfson Institute of Preventive Medicine, The Royal London and St. Bartholomew's Hospitals, London, UK

This review deals with the following genes involved in lipid metabolism: CETP, LCAT, LDL receptor, apoE, Lp(a), hepatic lipase and lipoprotein lipase. However it misses out details of the apoC3 gene which is the only one in which a specific therapy (volanesorsen) has been developed. A review of this can be found in Galton (2017) ${ }^{1}$.

The authors then go on to deal with the Hind 111 polymorphism of Lipoprotein lipase. A common HindIII polymorphism in intron 8 (T/G) of the LPL gene has been found to be associated with altered plasma TG and HDL-cholesterol, and CAD risk in several studies, but they do not comment on its functional significance.

It is known that certain intronic sequence contain regulatory elements that are important for transcription and translational regulation of a gene. A recent study (Chen et al. $(2008)^{2}$ ) showed that this Hind 111 polymorphism affects the binding site of a transcription factor that regulates the transcription of LPL gene. Electrophoretic mobility shift assays revealed that the HindIII site binds to a transcription factor and that the mutant allele has lower binding affinity than the wild type allele. Transcription assays containing the entire intron 8 sequence along with full-length human LPL promoter were carried out in COS-1 and human vascular smooth muscle cells. The mutant allele was associated with significantly decreased luciferase expression level compared to the wild type allele in both the muscle ( $3.394 \pm 0.022$ vs. $\left.4.184 \pm 0.028 ; P=4.7 \times 10^{-6}\right)$ and COS-1 $(11.603 \pm 0.409$ vs. $14.373 \pm 1.096 ; P<0.0001)$ cells. This study demonstrates for the first time that the polymorphic HindIII site in the LPL gene is functional because it affects the binding of a transcription factor and it also has an impact on LPL expression. 


\section{References}

1. Galton DJ: Clarifying complex inheritance: apolipoprotein C3 and atherosclerosis.Curr Opin Lipidol. 2017; 28 (4): 308-312 PubMed Abstract | Publisher Full Text

2. Chen Q, Razzaghi H, Demirci FY, Kamboh MI: Functional significance of lipoprotein lipase HindIII polymorphism associated with the risk of coronary artery disease.Atherosclerosis. 2008; 200 (1): 102-8 PubMed Abstract | Publisher Full Text

Is the topic of the review discussed comprehensively in the context of the current literature?

Partly

Are all factual statements correct and adequately supported by citations?

Yes

Is the review written in accessible language?

Yes

Are the conclusions drawn appropriate in the context of the current research literature? Yes

Competing Interests: No competing interests were disclosed.

I confirm that I have read this submission and believe that I have an appropriate level of expertise to confirm that it is of an acceptable scientific standard.

The benefits of publishing with F1000Research:

- Your article is published within days, with no editorial bias

- You can publish traditional articles, null/negative results, case reports, data notes and more

- The peer review process is transparent and collaborative

- Your article is indexed in PubMed after passing peer review

- Dedicated customer support at every stage

For pre-submission enquiries, contact research@f1000.com 